\title{
CORPORATE GOVERNANCE IN CANADA: A REVIEW OF REGULATION AND PRACTICES
}

\author{
Raef Gouiaa
}

* University of Québec in Outaouais, Canada

Contact details: University of Québec in Outaouais, 283 boulevard Alexandre-Taché, C.P. 1250, Succursale Hull, Gatineau (Québec), J8X 3X7, Canada

OPEN ACCESS
How to cite this paper: Gouiaa, R.
(2019). Corporate governance in
Canada: A review of regulation and
practices. Corporate Law \&
Governance Review, 1(2), 42-50.
http://doi.org/10.22495/clgrvli2p4
Copyright @ 2019 The Authors
This work is licensed under a Creative
Commons Attribution 4.0 International
License (CC BY 4.0).
https://creativecommons.org/licenses
/by/4.0/
ISSN Online: $2664-1542$
Received: 02.05 .2019
Accepted: 15.07 .2019
JEL Classification: G18, G32, G34,
G38, K22
DOI: $10.22495 /$ clgrvli2p4

DOI: $10.22495 /$ clgrvli2p4

\begin{abstract}
Emerging from the agency theory, corporate governance is the practice of ensuring a corporation conducts itself accountably, fairly and openly in all its dealings. The achievement of corporate performance relies on the mechanism efficiency of Corporate Governance both internally and externally. This study is intended to review the Canadian legal and practical landscape related to corporate governance and its external and internal mechanisms. One of the main goals of corporate governance is to ensure a company's executives are managing the finances effectively and that they always act in the best interest of stakeholders. Canada passed a law in 2003 to strengthen corporate governance. Based on the U.S. Sarbanes-Oxley Act (SOX), this Canadian law aims to create confidence in the Canadian market and protect investors from corporate scandals. Corporate governance mechanisms can be divided into internal and external mechanisms. The internal mechanism is essentially derived from the board of directors and its committees whereas the external mechanism is derived from laws and regulation, capital market, corporate control market, stock holders (ownership structure), and investor activities. The balance and effectiveness of the corporate governance mechanisms can create a better corporate financial performance.
\end{abstract}

Keywords: Corporate Governance, Board of Directors, Regulation, Corporate Control Market, Ownership, Performance

Authors' individual contribution: The author is responsible for all the contributions to the paper according to CRediT (Contributor Roles Taxonomy) standards.

\section{INTRODUCTION}

Corporate governance is the set of mechanisms, processes and relations by which corporations are controlled and directed (Shailer, 2004). Many great Canadian and international organizations can, without hesitation, relate their success to their effective governance practices. Over the past decades, the world has learned a lot from different economic leaders, scandals and outstanding profitable or crisis situations. With the incredible growth in different markets around the globe, governments now occupy a major role in refereeing the way public organizations conduct their affairs. When enacting legislation or regulations, due to globalization, countries can no longer operate on a national basis only. Legislators have the responsibility to consider numerous international factors. The laws, policies and principles that structure corporate governance today are continuously evolving achievements. They ensure transparency for shareholders, reasonable gratification for governance leaders and attempt to align these to the interests of stakeholders.

Like many markets, Canadian markets are highly influenced by American markets. Describing Canada's corporate governance situation isn't complete if we ignore the United States early $21^{\text {st }}$ century scandals. These scandals directly impact the Canadian way of regulating governance today. In 2005, 175 corporations listed in the Toronto Stock Exchange (TSX) that represented $61 \%$ of the total capital of its market were also listed in American markets (Bédard, 2005). Naturally, after the Enron scandals, Canadian investors rapidly demonstrated anxiety. Compared to a reactive approach implementing the Sarbanes-Oxley law as in the United States, Canada decided to proactively reform 
the way it dealt with corporate governance. More precisely, Canada's changes were principally in communication of financial information, audit committees, regulations towards auditors and sanctions (Bédard, 2005). This reform primarily changed how governance, that used to be based on principles that called upon a practitioner's professional judgment, has changed to our current situation consisting of multiple regulations. Boards of directors and audit committees were the ones to garner most of the criticism after the scandals. This is why the Canadian Securities Administrators (CSA) published their first edition of regulations 58-201 Corporate Governance Guidelines and 58-101 Disclosure of Corporate Governance Practices, both in April of 2005.

In Canada, even though a set of developed common law principles regarding corporate law exists, it is a fact well-known to practitioners that the securities commissions occupy a major role in establishing Canadian corporate governance practices (Liao, 2014). Legislators lack pertinent corporate experience and frequently avoid changing corporate legislation. Corporate law in Canada operates on a jurisdictional basis. The 10 provinces and 3 territories of the country control securities regulations and policies. Regulators from every region have grouped to form the Canadian Securities Administrators. This team seeks to develop a harmonized approach to securities regulation across the country (CSA, 2017). Although the CSA's mission is to protect investors from unfair, improper or fraudulent practices and it has fostered fair, efficient and vibrant capital markets, over the past decade, the CSA has been involved in changing legislature enacted by the Business Corporations Act regarding Governance. Some practitioners say that the CSA is constantly overstepping its jurisdiction; others reply that at least someone is shaping the development of corporate governance standards in Canada (Liao, 2013). Evidently, with the commissions playing a major role in leading the country's governance practices, Canada is pushed towards a more shareholder-centric model of governance (Liao, 2013).

This article is organized as follows. The second section presents the shareholders' rights protection. Board of directors' practices are the subject of the third section while the fourth section is devoted to the directors' remuneration practices. In the fifth section, we examine the representation of women in governance bodies. The committees of the board of directors, the ownership structures and the market of corporate controls are presented respectively in the sixth, seventh and eighth sections. The ninth section presents a review of the effect of corporate governance on firm performance in Canada. The final section reviews the main results, observations and contributions of this study.

\section{SHAREHOLDERS' RIGHTS PROTECTION}

When the CSA first started to come out with regulations on how governance should take place in Canadian corporations, many questioned the reasons why they were the ones bringing up issues upon this matter. Somehow, the CSA had decided to include corporate governance in their "public interest mandate". Over the years, subjects such as having more women on boards, the independence of board members and the codes of business conduct have come to light. The CSA was involved in making many important national policies that helped increase the overall quality of corporate governance in Canada, ensuring transparency for shareholders. Three very important policies structure the governance model of the country: National Policy 58201 on Corporate Governance Guidelines, National Policy 58-101 on Disclosure of Corporate Governance Practices and National Policy 52-110 Respecting the Audit Committee.

The content of these policies protects investors, dictating how boards of Canadian corporations should accomplish their mandate. They define the purpose of boards, they serve their shareholders' best interests, and also, lay out how to plan long term strategies, and insure performance and control risks. They deal with the composition of boards, how they should be evaluated on their effectiveness as they play different precise roles. Board members should be responsible, independent and experienced individuals able to have an open dialogue with shareholders. Their compensation should depend on the outcomes they achieve, and they should be elected by shareholders.

In order to ensure the representation of shareholders' interests in an organisation and to ensure that shareholders can exercise their rights, a set of Canadian statutes are in place. As previously mentioned, shareholders elect the directors who manage or supervise the management of the business and the affairs of the corporation (Hoffman \& Klotz, 2013). Directors are nominated by management with the help of the nominating committee and then elected. According to Canadian legislation, a director does not have the authority to exercise fundamental changes without shareholder approval. For instance, selling a big portion of an organisation's assets would need the shareholders' approval. Another good example would be the continuance, discontinuance or expansion of the corporation into another jurisdiction. When it comes to public corporations, rules of stock exchange, such as for the TSX, can require additional approval for certain circumstances that normal legislation wouldn't impose. An example could be carrying out transactions that materially affect the control of the corporation. Procedures on how shareholders can raise issues about the corporation to management are explained under the statutes. It is indicated here that shareholders who own at least $1 \%$ of the total voting shares or have held voting shares worth a minimum fair market value of $\$ 2,000$, for six months, can submit a proposal to raise a matter at a shareholders' meeting. Management has to give notice to the proposals and include brief statements in support of the proposal. A shareholder holding $5 \%$ of the voting shares of a corporation can demand a shareholders' meeting. If a shareholder feels that a corporation has violated his or her rights, a variety of actions can be undertaken, such as for instance, going to court. Minority shareholders rights are also protected. For example commissions from provinces such as Ontario and Quebec have adopted policy 61101 Protection of Minority Security Holders in Special Transactions. The following diagram is the ideal model of a governance structure that should be in place in Canadian Corporations. Evidently, shareholders are at the top of the hierarchy since they own corporations. 
Figure 1. Model of corporate governance (based on Hansell, 2003)

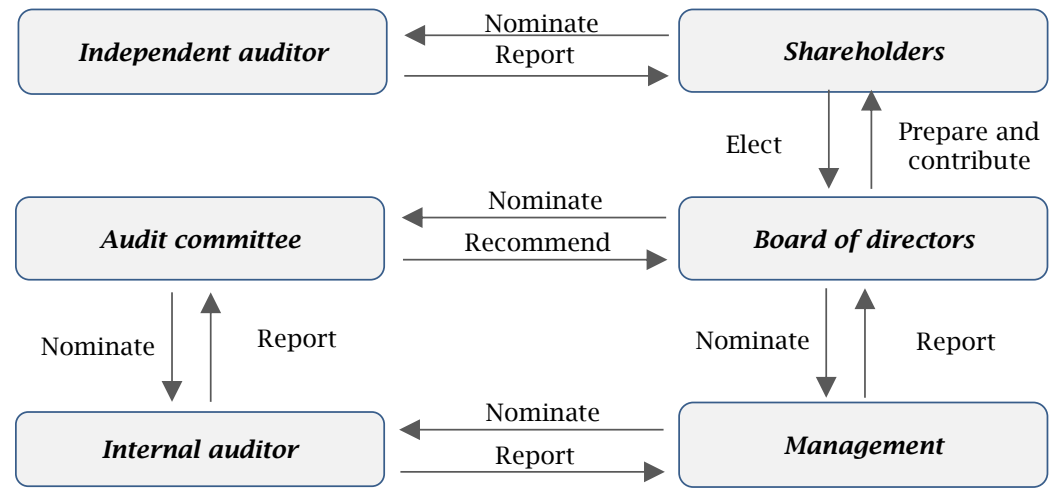

There is a very important relationship between the external auditor, the board of directors and the shareholders. The external auditor emits an opinion on the financial information reported by the issuer. The external auditor is hired and paid by the board and has a mandate of protecting the shareholders by validating that the issuer has reported reliable information. Financial information is the most important variable when it comes to shareholders making decisions. Naturally, regulations and internal auditors must ensure that the external auditor is as independent as he or she can be. Independency ensures that the external auditor is not influenced by the issuer and gives a non-biased opinion. Under the shareholders in the diagram are the elected board members in charge of overseeing corporations' activities. In small private companies, shareholders and directors are normally the same people. This means there is no real division of power and financial information is reported for reasons other than public interest. When it comes to large public corporations, the board has more of a supervisory role with respect to executive officers at the management level. The audit committee's role is to help the board of directors fulfil their responsibility of monitoring the process of financial reporting. The internal auditor watches over management activities and reports to the audit committee regarding improper activities or controls and recommends enhancements of practices.

Financial information is not only very important for shareholders but also for many other stakeholders' decision processes. Customers, suppliers, employees, lenders and local communities have a stake in, and are affected by, a firm's success or failure (Heath \& Norman, 2004). Of course, since shareholders are providers of capital, owners and finance corporations on a long term basis, management and corporate law tend to adopt a more shareholder-oriented governance way of thinking. As mentioned before, governance leaders must attempt to align the interests of all stakeholders. This practice is very beneficial in the long run; a successful corporation aims to develop strong relationships with all of its stakeholders thus contributing to its competitive advantages and ensuring its future existence. With financial information being highly important for many parties, Canada regulated the reporting of corporations with the National Policy 52-201 entitled Disclosure Standards. These standards are very similar to American standards and do not need to be presented in this work. A more relevant policy regarding governance in Canada is the corporate governance guidelines.

\section{BOARD OF DIRECTORS' PRACTICES}

The purpose of policy 58-201 is to provide guidance on governance practices. The following summary of the guidelines consists of addressing the primary topics of NP 58-201 which have been composed to balance out the protection of investors as well as fostering confidence, fairness and efficiency in capital markets. The policy also aims to take into consideration the development and continuous involvement of corporate governance in the United States and around the world. A reality of the Canadian corporate landscape is that there is a very large number of small companies and controlled companies that also need to follow governance regulations. This is taken into consideration in NP 58-201 since these entities do not necessarily have the same available resources as larger corporations to enable them to comply with specific policies.

\subsection{Composition of the board of directors}

The board should have a majority of independent directors; a director is independent if he or she has no direct or indirect material relationship with the issuer. According to regulation 52-110 Respecting Audit Committees, a "material relationship" is a relationship which could be reasonably expected to interfere with the exercise of a member's independent judgment. National Policy 58-101 elaborates that the board of directors must disclose the identity of directors who are independent as well as the ones that are not independent. The board must disclose if a director is participating in any other issuing entity. Independent directors need to disclose the frequency of their meetings without the non-independent members. It is very important to disclose whether the chair of the board is independent or not.

\subsection{Meetings of independent directors}

The independent directors should hold regularly scheduled meetings at which non-independent directors and members of management are not in attendance (NP 58-201). National policy 58-101 indicates that an attendance record of each member for all meetings must be disclosed. 


\subsection{Board mandate}

A board should have a written mandate where members recognize their responsibility on managing the issuer. The mandate should explain how the board ensures the integrity of the chief executive officer (CEO) and other executives as well as how it ensures that an organizational culture of integrity is implemented by the CEO and other executive officers. The mandate must describe how the board is going to adopt and approve (at least once a year) a strategic planning process that includes an enumeration of the opportunities and risks of the organization. The written mandate should define how the board is going to illustrate the principal risks of the business and how it intends to manage risks. The board members have the responsibility of creating a detailed succession plan. The board must indicate how it intends to communicate with the issuer and what its responsibility is regarding the issuer`s internal controls and management information systems. The mandate has to explain how the board is going to develop and implement policies towards the issuer's approach on corporate governance. National Policy 58-101 states that the board of directors must disclose the text of the board's written mandate.

\subsection{Position descriptions}

The board should develop clear position descriptions for the chair of the board and the chair of each board committee. In addition, the board, in collaboration with the CEO, should develop a clear position description for the CEO, which includes a layout of management's responsibilities. The board should also develop or approve the corporate goals and objectives that the CEO is responsible for meeting (NP 58-201). According to National Policy 58-101, the board must disclose if it has a written position description for the chair of the board, all of its committees and for the CEO.

\subsection{Orientation and continuing education}

The board is responsible for providing an orientation to all new directors. After an orientation, directors should understand the role of the board including its committees and the purpose of each executive officer. Of course, new directors need to comprehend the operations of the issuer's organisation. Directors should have access to continuing education opportunities. This will maintain and enhance the quality of their contribution to the business. National policy 58-101 indicates that the board must briefly describe the measures it takes to orient new directors and what measures it takes to provide them with continuing education.

\subsection{Code of business conduct and ethics}

The board should adopt a written code of business conduct and ethics. The code should be applicable to directors, officers and employees of the issuer. The board should be responsible for monitoring compliance with the code. The code should constitute written standards that are reasonably designed to promote integrity and to deter wrongdoing. In particular, it should address conflicts of interest, protection and proper use of corporate assets, confidentiality of corporate information, compliance with laws, rules and regulations, reporting of any illegal or unethical behaviour and fair dealing with the issuer's security holders, customers, suppliers, competitors and employees (58-201). Compared to the United States, Canadian corporations are obligated to achieve a balance in meeting all stakeholders' expectations (Gendron, Messabia, \& Rivest, 2016). According to National Policy 58-101, the board must disclose if they have a written code and describe how it ensures that the directors exercise independent judgement in accomplishing their jobs. The board also has to explain how it promotes a culture of ethical business conduct.

\subsection{Nomination of directors}

A nominating committee should be appointed by the board. The committee should only be composed of independent directors and should adopt a written charter indicating its mandate, responsibilities and procedures on when and how to communicate with the board, also, the qualifications and authority of its members. The nominating committee is responsible for determining the competencies and skills needed in board members, the appropriate size of the board in order to facilitate decision making and identifying individuals qualified to become new board members. National Policy 58-101 indicates that the board must disclose its process in identifying potential new candidates for board nomination. If the board has a nominating committee, it has to describe all of its members and their responsibilities and authorities. National Policy 58-101 also indicates that boards must disclose director term limits and other mechanisms of board renewal.

\subsection{Regular board assessments}

The board, its committees and each individual director should be regularly assessed with regard to the effectiveness and the contribution made to the organisation by each one (NP 58-201). National Policy 58-101 indicates that a board must disclose if directors are regularly assessed regarding their effectiveness and contribution.

\section{DIRECTORS' REMUNERATION PRACTICES}

The issue of directors' remuneration has received an increasing attention in recent times. In particular, the fact that directors themselves are responsible for setting their own remuneration may create a conflict of interests, resulting in high pay levels, barely linked to the activity they perform (ratification and monitoring of Chief Executive Officer (CEO) decisions). Under these circumstances, traditional codes of good governance, at international and national level, have recommended some measures to control the remuneration granted to directors (Manzaneque, Merino, \& Ramírez, 2015). A compensation committee should be appointed by 
the board of directors. The committee should only be composed of independent directors and should adopt a written charter indicating its mandate, responsibilities and procedures on when and how to communicate the matter of compensation to the board, and also, the qualifications and authority of its members. According to National Policy 58-101, the board must disclose its procedures regarding the determination of the issuer's directors' and officers' compensations. If the board has a compensation committee, it has to describe all of its members and their responsibilities and authorities. Compensation is a subject that is frequently addressed in corporate governance since it can be used as a control lever ensuring that responsibilities delegated are accomplished, thus contributing to a corporation's long-term strategies. Since the year 2000, board members' compensation has doubled in Canada (Magnan, 2014). Although United States corporations pay higher compensation to their board members, Canadian corporations have one of the highest compensation levels in the world. Furthermore, over the 10-year period from 2001 to 2010, the average annual fees received by directors of Canadian public corporations have effectively increased substantially from $\$ 17,044$ to $\$ 79,000$, or an increase of $465 \%$ (Magnan, 2014). In Canada, 7 out of the 10 corporations that pay board members the most are active in the resources sector (oil, gas, oil and gas pipelines, mines); according to the survey of the 100 largest Canadian corporations conducted by Spencer Stuart, in 2011, the average compensation for board members of a resource sector varied between $\$ 180,000$ to $\$ 190,000$ compared to the rest of large Canadian corporations at an average of $\$ 98,000$. In comparison, the compensation paid to the directors of the French company Total, a giant in the global oil industry, is within the range of 60,000 to 163,000 euros, with the median being about 70,000 euros (about $\$ 98,000$ ) (Magnan, 2014). The main reason why compensation has increased so fast is simply because more is expected from board members, especially with the numerous national policies that have been enacted in the past two decades due to American scandals. Naturally, when someone's workload is increased, the salary is expected to rise proportionally as well. Does this mean that the enormous increases of compensation witnessed since 2000 for board members are reasonable? Many argue that paying board members so much affects their economical independency to the issuers which directly influences their professional judgement regarding the correct accomplishment of their duties. One of the largest institutional investors in Canada, the Ontario Teachers' Pension Plan (OTPP) stated "...we believe there is a point at which the amount of compensation may negatively impact a director's ability to act independently. In determining this "'tipping point', we may consider a peer comparison and/or our assessment of decisions taken by the board and/or directors." The IGOPP published a policy paper on the issue in which it recommended that the debate on directors' independence should be refocused on legitimacy and credibility (Allaire, 2008). According to this policy paper, directors' independence as advanced by the regulatory authorities and pressure groups is only one facet of legitimacy, and "While it is legitimacy that gives a board the authority to impose its will on management, it is credibility that makes a board effective and value-creating" (Allaire, 2008). Unless we investigate every board member's personal financial situation, we cannot comment on a particular board member's economic dependency on compensation earned as a director. Legislation and regulations should focus on whether or not the compensation implemented is a control that ensures the effectiveness and contribution expected from a board member. In order to do so, we must ensure that every board member's roles and responsibilities are well defined and understood. Although Canada isn't in a crisis regarding directors' compensation, over the past decades their pay has substantially increased. In order to ensure that reasonable compensation is implemented, many principles have been developed. The following are two examples of policies relating to principles enacted by the Canadian Institute of Chartered Accountants and The Canadian Coalition for Good Governance (CCGG).

a) Seven Director Pay Principles and Goals by the Canadian Institute of Chartered Accountants (Greville \& Crawford, 2004):

- Directors should be adequately compensated for their time and effort.

There should be no distinction in pay for board members performing similar roles (time and effort).

Distinctions should be made for board members with greater responsibilities (e.g., committee service, committee chair, board chair).

Share ownership is a critical goal.

The quantum of a mandatory director share investment for a particular board should be set at a level that recognizes the financial position of different board members (i.e., accommodate directors with lower economic means).

Director tax efficiency should not be the main driver of director compensation design.

Setting and disclosing director pay should be a deliberate and transparent process.

b) The Canadian Coalition for Good Governance suggestions towards directors' compensation: These suggestions promote independent thinking by the directors while aligning their interests with those of the shareholders and should reflect their expertise and time commitment to their duties. They also promote shareholding by directors, aiming to make this to be the least complex and most transparent; and possibly may also be subject to shareholder approval.

\section{THE REPRESENTATION OF WOMEN IN GOVERNANCE BODIES}

Gender representation on the board refers to an appropriate mix of male and female executives in the corporate board of directors (Grosvold, Rayton, \& Brammer, 2016). However, there is a global concern that men dominate the corporate boards. This asymmetry in male and female representation has attracted concern in public and private sectors (World Economic Forum, 2013). The desire by governments and organisations to reduce the disproportionality on corporate boards is part of the advocacy in the principle of equality of treatment 
(Fineman, 2014). The role of women in the boards has been discovered to spur sustainability performance and disclosure in some countries (Fernandez-Feijoo, Romero, \& Ruiz-Blanco, 2014; Modiba \& Ngwakwe, 2017).

The regulations on disclosing corporate governance practices have many policies regarding the participation of women in boards and executive officer positions. In 2007, 46\% of public corporations had only one female board member and $51 \%$ had two or three (Dion, 2007). During the years 2000 to 2010, the percentage of women's representation in boards stagnated between 13\% and $17 \%$ for public corporations (St-Onge \& Magnan, 2010). In the past two decades, Canada has made reasonable efforts in increasing opportunities for women in the governance line of work. Contrary to many countries like Norway and Spain who adopted legislation imposing targeted ratios of female presence in corporate governance positions, Canada decided to adopt a more incentive-based approach (St-Onge \& Magnan, 2010). National Policy 58-101 is the perfect example of a set of regulations that encourage corporations to increase governance position opportunities for women. Here are five specific topics from the national policy, related to women in industry:

a) Policies Regarding the Representation of Women on the Board: Boards must indicate if issuers have adopted written policies regarding the identification and nomination of women directors. Indications include a summary of the policies' objectives, the measures in place to ensure the implementation of the policies, the progress in achieving the objectives of the policies and what indicators are used to evaluate the effectiveness of the policies.

b) Consideration of the Representation of Women in the Director Identification and Selection
Process: The board of directors must indicate how it or its nominating committee considers women's representation on the board during the nomination of candidates. If a certain level of female representation for election isn't considered by the issuer, the reasons why must be disclosed.

c) Consideration Given to the Representation of Women in Executive Officer Appointments: Indications regarding the issuer's consideration of women's representation for executive officer appointments must be disclosed. If a certain level of female representation isn't considered by the issuer, the reasons why must be elaborated.

d) Issuer's Targets Regarding the Representation of Women on the Board and in Executive Officer Positions: The issuer's targeted percentage of women's participation in boards and executive officer positions must be disclosed. Progress towards reaching its targets must be indicated and reasons why targets aren't reached must be explained.

e) Number of Women on the Board and in Executive Officer Positions: The percentage of board members and executive officers that are women must be disclosed.

By making corporations disclose all this information regarding a female presence in their governance practices, the CSA indirectly encourages organisations to increase female representation regarding director and executive officer positions. Since the appearance of a women policy in NP 58101, many Canadian researchers have conducted studies on the advantages of having a balance of gender for members occupying board and executive positions. These advantages have proven to influence corporations in creating more opportunities for women in Canadian governance jobs.

Table 1. Percentage of women on the board of directors and in executive positions

\begin{tabular}{|l|l|l|l|l|l|}
\hline & 2011 & 2012 & 2013 & 2014 & 2015 \\
\hline \% Women on the board (Canada) & 0.097 & 0.109 & 0.114 & 0.126 & 0.137 \\
\hline No woman on the board (Canada) & 0.445 & 0.417 & 0.402 & 0.331 & 0.287 \\
\hline \% women in executive positions (Canada) & 0.089 & 0.102 & 0.116 & 0.137 & 0.164 \\
\hline
\end{tabular}

The above statistics, based on a sample of 162 Canadian companies listed on the Toronto Stock Exchange (TSX Composite), show that the percentage of women on boards of directors and in senior executive management of Canadian companies increased from 2011 to 2015.

As with many policies related to Canadian governance, a very relevant control has been applied; the "comply or explain" policy. If Canadian corporations don't comply with regulations towards female representation in board and executive positions, they will be asked to explain why. Whether the reason is valid or not, an adapted solution will be proposed in order to correct or respect national policies in relation to women representation.

\section{THE COMMITTEES OF THE BOARD OF DIRECTORS}

Committees are created by board resolutions. These committees are formed in order to assign certain responsibilities to specialised administrators. These delegations do not mean that boards are no longer responsible for the tasks. Usually, three main committees are relied upon: the nominating committee, the compensation committee and, most importantly, the audit committee.

\subsection{Nominating committee}

As previously explained in NP 58-201, a nominating committee should be appointed by the board. The committee should only be composed of independent directors and should adopt a written charter indicating its mandate, responsibilities and procedures on when and how to communicate with the board, and also, the qualifications and authority of its members. The nominating committee is responsible for determining the competencies and skills needed in board members, the appropriate size of the board in order to facilitate decision making and identifying individuals qualified to become new board members. 


\subsection{Compensation committee}

As previously explained in NP 58-201, a compensation committee should be appointed by the board. The committee should only be composed of independent directors and adopt a written charter indicating its mandate, responsibilities and procedures on when and how to communicate the matter of compensation with the board, also, the qualifications and authority of its members. According to National Policy 58-101, the board must disclose its procedures regarding the determination of the issuer's directors' and officers' compensations. If the board has a compensation committee, it has to describe all of its members and their responsibilities and authorities.

\subsection{Audit committee}

The need for audit committees across organisations came amidst of unexpected failures that stem from corporate misconduct (Dodo, 2017; Dlamini, Mutambara, \& Assensoh-Kodua, 2017). Formation of audit committees in organization results in substantial benefits (Badara \& Saidin, 2014). With the continued changes in business environment, and an increase in complexities within the modern municipalities and companies, the need for the establishment of audit committees to enhance the governance process is increasingly compelling (Dodo, 2017).

The Audit committee is the only regulated committee in Canada. The first edition of regulation 52-110 Respecting Audit Committee was first published on March $30^{\text {th }}$, 2004. It describes that the committee's role is to help the board of directors in fulfilling their responsibility of monitoring the process of financial reporting. The committee facilitates communication between the CEOs, the board of directors and the external auditors and insures complete independence. Of course, the Audit committee gets most of its work done by their internal auditor who has a key role in identifying and evaluating a corporation's principal risks. The internal auditor ensures the integrity of financial information and aims to enhance operational activities. According to the policy, the committee must have a written mandate explaining its responsibilities. One of its important responsibilities is to recommend an external auditor to the board as well as the auditor's compensation. The committee is directly responsible for overseeing the external auditor's work and is in charge of resolving any disagreements between the auditor and management. The audit committee is required to examine all financial statements, management reports and information regarding the financial status of the corporation. Since the regulation first came out, many modifications have been enacted to ensure that financial information is reliable.

\section{OWNERSHIP STRUCTURES}

Various corporate governance mechanisms are proposed to address issues of divergence of interests and to reduce agency costs associated with conflicts. The ownership structure is an important part of this and can affect significantly the value of the firm. Abu Haija and Alrabba (2017) results show that there is a positive relationship among managerial, institutional and family ownership with financial performance, while there is no significant relationship between foreign ownership and firm's financial performance. These results confirm some previous studies, such as Asadi and Pahlevan (2016) who found that corporate performance is influenced by ownership structure.

The Canadian corporate governance system is characterized by the presence of significant shareholders. This leads to a great dependence on the concentration of capital as a mechanism for aligning interests and controlling agency costs. Indeed, Canada has fewer widely-held firms than the United-States, with more ownership by families and financial institutions (King \& Santor, 2008). Canadian firms are also more likely to use either pyramids or dual-class shares than do their American counterparts.

\section{MARKET OF CORPORATE CONTROLS}

Canada is considered a very bidder friendly jurisdiction. National Policy 62-202 Take-Over Bids Defensive Tactics leaves Canadian boards with a limited number of defences when faced with an unsolicited takeover bid (Liao, 2014). National Policy 62-202 sets out the view of the Canadian securities regulatory authorities on take-over bid defensive tactics. The Canadian securities regulatory authorities are of the view that the take-over bid provisions of Canadian securities legislation should favour neither the offeror nor the management of the target company and should leave the shareholders of the target company free to make a fully informed decision. The Canadian securities regulatory authorities are prepared to examine target company tactics in specific cases to determine whether they are abusive of shareholder rights. If they become aware of defensive tactics that are likely to deny or severely limit the ability of shareholders to respond to a take-over bid or to a competing bid, they will take appropriate action. The National Policy also provides that prior shareholder approval of corporate action would, in appropriate cases, allay the concerns of the Canadian securities regulatory authorities.

\section{CORPORATE GOVERNANCE AND FIRM PERFORMANCE}

The recent financial crisis that hit the global economy and the scandals that affected several large companies in the world contributed to showing the importance of corporate governance. It has also increased the interest of researchers and policymakers for thorough and detailed analyses on corporate governance and disclosure transparency. A review of the academic and professional managerial literature shows the importance of the board of directors in the corporate governance system; the board allows management to assist and control in the fulfilment of its mandate to protect the rights of shareholders and investors and consequently to improve company value (Fama \& Jensen, 1983; Zéghal \& Gouiaa, 2009). However, the effectiveness of this governance mechanism in 
fulfilling its roles and functions largely depends on its characteristics (Harris \& Raviv, 2008). In a research study conducted on a sample of 192 Canadian companies in 2010, Gouiaa and Zéghal (2015) analysed the effect of board characteristics on financing costs of Canadian corporations. The obtained results reveal that larger boards, composed of competent and experienced directors including those where women are represented, in which the functions of the chairman and CEO are separated, which have a large, independent audit committee, and which meet more regularly, allow for a significantly improved transparency of disclosure through a broader level and with more detailed information. In addition, they show that larger boards composed of experienced and qualified directors, with greater ownership of independent directors, with larger audit committees, and in which financial institutions and women are represented can significantly reduce the financing costs by equity capital and debt as well as the average cost of capital. The results indicate that boards whose characteristics meet the requirements of good governance promote efficient control of management and the accounting and financial reporting process, and consequently allow greater disclosure transparency, together leading to significantly reduced costs of financing by debt as well as by equity capital. The results show that the size of the board, its tenure, and size of its audit committee have a negative and statistically significant effect on the cost of equity. These results also show that boards of directors where women and financial institutions are represented allow for reducing the cost of financing. Examination of the results of the model analysing the effect of board characteristics on the cost of debt shows that larger boards with greater ownership of independent directors, larger auditing committees and experienced and competent directors and where financial institutions are represented allow for reducing the cost of financing by debt. Finally, the review of the results of the regression model analysing the effect of board characteristics on the average cost of capital shows that larger boards, composed of qualified and experienced directors and in which financial institutions are represented, enjoy a lower average cost of capital.

\section{CONCLUSION}

In recent years, increasing attention has been paid to corporate governance around the world particularly after the collapse of several international companies and recurring financial crises. Therefore, corporate governance mechanisms have been constantly evaluated and reformed by policymakers and market participants to develop a framework of best governance practices that can improve firm performance and avoid such crises. Compared to a reactive approach such as that of implementing the Sarbanes-Oxley law in the United States, Canada decided to proactively reform the way it dealt with corporate governance by adopting corporate governance guidelines that promote transparency and are based on the comply or explain principle. This reform primarily changed how corporate governance, which used to be based on principles that called upon practitioners' professional judgment, has now changed to our current situation consisting of multiple regulations.

The securities commissions are now playing a major role in shaping Canadian corporate governance practices. By virtue of the fact that the securities commissions have a public interest jurisdiction to protect the capital markets, their influence has pushed Canada toward a more shareholder-centric model of governance increasing, therefore, shareholders' rights beyond the Canadian corporate law (Liao, 2014). One of the limitations of this paper is its focus on one country. Further research is recommended to consider including other countries from different legal and cultural contexts to see how the results and observations might differ.

\section{REFERENCES}

1. Abu Haija, A. A., \& Alrabba, H. M. (2017). Relationship between ownership structure and financial performance. Corporate Ownership \& Control, 14(3-2), 393-398. https://doi.org/10.22495/cocv14i3c2art13

2. Allaire, Y. (2008). The independence of board members: A quest for legitimacy (Policy Paper No.3). Retrieved from http://igopp.org/wp-content/uploads/2014/04/PP_IndependanceAdmin_EN_v4-2.pdf

3. Asadi, A., \& Pahlevan, M. (2016). The relationship between ownership structure and firms' performance in Tehran Stock Exchange. Journal of Insurance and Financial Management, 1(2), 72-86.

4. Badara, M. A. S., \& Saidin, S. Z. (2014). Internal audit effectiveness: Data screening and preliminary analysis. Asian Social Science, 10(10), 76-85. https://doi.org/10.5539/ass.v10n10p76

5. Bédard, J. (2005). Commentaire. La réponse canadienne aux scandales financiers des États-Unis. Gestion. 30(3), 20-27. https://doi.org/10.3917/riges.303.0020

6. CSA. (2017). Canadian Securities Administrators. Retrieved from http://www.securities-administrators.ca

7. Dion, M. (2007). Les conseils d'administration de grandes entreprises canadiennes et les directives de gouvernance (1997-2005). Droit et société, 67(3), 695-711.

8. Dlamini, Z. V., Mutambara, E., \& Assensoh-Kodua, A. (2017). An investigation into the effectiveness of audit committees. Corporate Board: Role, Duties and Composition, 13(2), 46-54. https://doi.org/10.22495/cbv13i2art5

9. Dodo, A. A. (2017). Corporate collapse and the role of audit committees: A case study of Lehman Brothers. World Journal of Social Sciences, 7(1), 19-29.

10. Fama, E. F., \& Jensen, M. C. (1983). Separation of ownership and control. Journal of Law and Economics, 26(2), 301-325. https://doi.org/10.1086/467037

11. Fernandez-Feijoo, B., Romero, S., \& Ruiz-Blanco, S. (2014). Women on boards: Do they affect sustainability reporting? Corporate Social Responsibility and Environmental Management, 21(6), 351-364. https://doi.org/10.1002/csr.1329

12. Fineman, M. A. (2014). Equality and difference - The restrained state. Alabama Law Review, 66(3), 609-626.

13. Gendron, D., Messabia, N., \& Rivest, D. (2016). Contrôle interne: Une approche gestionnaire. Montreal, Canada:

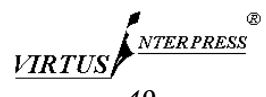


Chenelière Éducation

14. Zéghal, D., \& Gouiaa, R. (2009). The effect of board of directors' characteristics on the cost of capital of the French companies. Corporate Ownership \& Control, 7(1-2), 250-264. https://doi.org/10.22495/cocv7ilc2p1

15. Gouiaa, R., \& Zéghal, D. (2015). Analysis of the effect of corporate governance attributes and disclosure level on firms' costs of financing. Journal of Modern Accounting and Auditing, 11(11), 561-580. https://doi.org/10.17265/1548$6583 / 2015.11 .002$

16. Greville, E., \& Crawford, D. (2004). 20 questions directors should ask about director compensation. Retrieved from https://www.transformgcc.com/resources/References_FP/Director\%20Compensation.pdf

17. Grosvold, J., Rayton, B., \& Brammer, S. (2016). Women on corporate boards: A comparative institutional analysis. Business \& Society, 55(8), 1157-1196. https://doi.org/10.1177/0007650315613980

18. Harris, M., \& Raviv, A. (2008). A theory of board control and size. The Review of Financial Studies, 21(4), 17971832. https://doi.org/10.1093/rfs/hhl030

19. Hansell, C. (2003). What directors need to know: Corporate governance. Toronto, Canada: Thomson Carswell.

20. Heath, J., \& Norman, W. (2004). Stakeholder theory, corporate governance and public management: What can the history of state-run enterprises teach us in the post-Enron era? Journal of Business Ethics, 53(3), 247-265. https://doi.org/10.1023/B:BUSI.0000039418.75103.ed

21. Hoffman, J. M., \& Klotz, J. M. (2013). Canada. In A. Kawamura, A. Mori \& Tomotsune (Eds.), Corporate governance. Jurisdictional comparisons ( $1^{\text {st }}$ ed.). London, England: Sweet \& Maxwell.

22. King, M. R., \& Santor, E. (2008). Family values: Ownership structure, performance and capital structure of Canadian firms. Journal of Banking \& Finance, 32(11), 2423-2432. https://doi.org/10.1016/j.jbankfin.2008.02.002

23. Liao, C. (2013). A Canadian model of corporate governance: Insights from Canada's leading legal practitioners (Research report, Canadian Foundation for Governance Research (CFGR)). Retrieved from http://www.cfgr.ca/docs/reports/InsightsFromLeadingPractitioners_CarolLiao.pdf

24. Liao, C. (2014). A Canadian model of corporate governance: Where do shareholders really stand? Director Journal, Institute of Corporate Directors (ICD), 36-38.

25. Magnan, M. (2014). Rémunération des administrateurs et gouvernance: Enjeux et défis. Retrieved from https://igopp.org/wp-content/uploads/2014/05/IGOPP_Rapport_administrateurs_FR_WEB-1.pdf

26. Manzaneque, M., Merino, E., \& Ramírez, Y. (2015). Relationship between directors' compensation and business performance: One issue to debate. Corporate Board: Role, Duties and Composition, 11(3), 166-175. https://doi.org/10.22495/cbv11i3art13

27. Modiba, E. M., \& Ngwakwe, C. C. (2017). Women on the corporate board of directors and corporate sustainability disclosure. Corporate Board: Role, Duties and Composition, 13(2), 32-37. https://doi.org/10.22495/cbv13i2art3

28. Shailer, G. (2004). An introduction to corporate governance in Australia. Sydney, Australia: Pearson Education.

29. St-Onge, S., \& Magnan, M. (2010). Les femmes au sein des conseils d'administration: Un bilan des connaissances (Série scientifique CIRANO 2010s-41). Retrieved from https://www.cirano.qc.ca/files/publications/2010s-41.pdf

30. World Economic Forum. (2013). The Global Gender Gap Report. Retrieved from http://www3.weforum.org/ docs/WEF_GenderGap_Report_2013.pdf 